\title{
R̊sulitm Ṗotes.
}

BY I'RANK l. NORBLRY, M.D.

Jacksonville, III.

\section{Eastem Mrichigan Asylum, at Pontiac, Bi- ennial Report, 189:.}

Sursicai Work-Operation of castration for the relief of sickening neuralgia of the testicle. The patient being a case of melancholia, and had been under treatment since I886. Had suffered great pain, localized in left testicle; operation, May I9, I890: testicle extirpated; improvement noticed in mental condition at once. Following December right testicle bccame similarly affected; it was removed in January, I89I : permanent improvement both mental and pliysical followed; patient discharged recovered, in March, I89I, and has since continued to improve. Examination of testicle showed chronic congestion with inflammatory deposits; some increase in connective tissuc, and in various localities small foci resembling tubercles. A case showing intimate relation of morbid peripheral irritation and physical and mental states, relicved by surgical interference. Much good can be accomplished by well-directed surgical treatment in many cases of hyperchondriacal insanity unmarked by signs of pronounced dementia.

Alimentation of the Insant--This problem is of paramount importance. Associated with acute mental disease is physical decline. Insanity is, in majority of cases, but an expression of impaired physical health and mal-nutrition of the brain. Dietetic management is, thercfore, important. Patients refuse from various causes, hence many difficulties stand in the way of systematic dieteties in the treatment of insanity. Tact, care, and thought is necessary to overcome objections. Whims of all but a few can be thus met. Forced feeding is becoming less and less frequent with accumula- 
tion of experienee. Forced feeding creates more harm than good. Tablespoonful of milk at intervals of one hour is better for nutrition purposes than large amount of food by artificial feeding. Lemonate recommended in cases of great excitement attended with exhanstion.

Patients during doliriant stares of maniacal excitement should not be fed by foreed feeding. The exhaustion of the process dangeronts to life. impairs digestion. produces romiting, adds to exhaustion.

\section{Alabuma Insome Asylum, at Thesculoosa, Bi- ennial Hrport, 189:.}

Tubroulosis among thi Insanc-The subject of tuberculosis among the insanc has attracted much attention during some years past: the principal point of practical interest to alienists being its possible causative influence in the production of mental aberration.

Experience shows that so-called "phthisical insanity" differs in no essential particular from mental alienation attendant upon other forms of chronic disease; typical instances of the suspicion, depression, systematized delusions and other symptoms detailed by Clonston and others being seen in the contse of chronic renal disease, valvular heart discase, etc. It is worthy of note that in event the tuberculosis runs an acute and rapicl course, acute maniacal excitement is its most psychic symptom. This has been especially noticed among the negro paticnts.

Brighls Discasc-Brights Hiscase is found to be extraordinarily common among the patients, it being, in fact, the most frequent form of bodily clisease with which we have to deal in the treatment of insanity, Albumen and casts are found constantly present in the urine of more than one half of the patients brought to the hospital.

labiular Iliart Lesions. - A third form of chronic defect, which equally with the two above montioned exerts a probable influence upon mental character, is valvular heart clisease, which, while but rarely a direct cause of death, is present in some eleren per eent. ot the patients treated. 
'lable showing the number and distribution of heart lesions found in 702 white insane patients.

Number examined.

Number showing valvular lesions. i 4 I

Mitral insufficiency. . . : 2

Iitral stenosis. . . .

Aortic insufficiency. . . 2

Aortic stenosis. . .

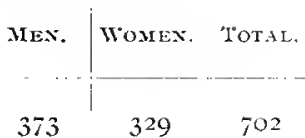

I $\quad 4$ I $\quad \mathrm{S}_{2}$

$\begin{array}{lll}29 & 29\end{array}$

$3: 6$

$2 \quad 2 \quad 4$

$9 \vdots 76$

The percentage of lesions among men, . . . 10.99

The percentage of lesions among women, . . I 2.46

Average, . . . . . . 11.72

Forms of insanity of eighty-two patients having heart 1esions:

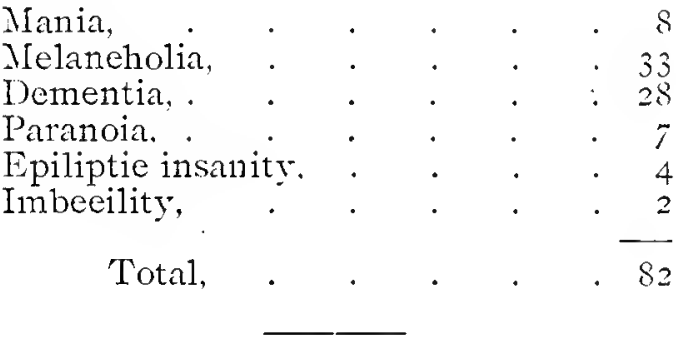

BY HALSFY L. WOOD, M.D.

\section{Relative to Conformity in the Lan of Com- mitment of the Insane.}

Dr. Stephen Smith of this eity, as Chairman of the Committce on the Commitment and Detention of the Insane, made a report in June last to the National Conference of Charities at their meeting in Denver, Col., urging unification of the laws of the States relative to the commitment of the insane. This report is printed in full in the October number of The American Journal of Insanity, and from which we quote:

It would seem that there eould be no question as to the importance of this measure. In these United States, 
there are nine different methods by means of which an insane person can be legally deprived of his liberty: and these vary widely. The benefits resulting from such unification would be, that, not only legal processes would be simplificd, but that the broad lines upon which the plan would be drawn would abolish certain defective and inhuman methods of commitment now in vogue in certain of the older States, as well as inaugurating wise methods in those States more recently formed, and those yet to rcceive the dignity of Statehood.

In five States, two being of the original thirteen, the unfortunate can be deprived of his liberty and committed to custody on the simple dictum of a Justice of the Peace. Witnesses are called to assist the justice in forming his opinion, but his is considered the expert opinion and upon it alone is the commitment ordered. These States are Tirginia, North Carolina, West Virginia, Tennesee, and Indiana. In Pennsylvania and Rhode Island the method of commitment rests upon the decision of physicians alone. "In the former State, the certificate of insanity, of the physicians, is conclusive; the judge merely certifying to the genuineness of the signatures and the character of the signers. In the latter State, even this formality is dispensed with in a certain class of cases, and the only requirement is that the superintendent of the hospital shall know of the good-standing of the certifying physicians."

And this contrast of the two methods shows clearly the progress that has been made toward a better management of the insane. In the first, closely resembling that followed at the commencement of the century, and the last the highest point yet reached in the development of the present. Between these two systems is seen a gradual growth in procedure to more rational methods.

We give the nine methods of commitment:

I. Commitment on the decision of Justices of the Peace. Five states.

II. Commitment on the decision of a judge. Eighteen states, two territories.

III. Commitment on the verdict of a jury of laymen. Five States.

IV. Commitment on the verdict of a mixect jury of laymen and physicians. Three states.

$v$. Commitment on decision of the Chancellor of the State. One state.

VI. Commitment on decision of a commission appointed by a judge. Four states. 
VII. Commitment on decision of Commissioners of Insinity. 'Three states.

VIII. Commitment on decision of an Assvlum Board. Two states.

IX. Commitment on the decision of physicians. Nine states, and I)istrict of Columbia.

"In the commitment of the insane on the decision of medical men alone, we have the highest development of this proceeding yet placed upon the statute book. 'The true nature of insanity is fully recognized, and the insane are remored from the category of criminals, and placed among that class of sick persons requiring medical care and treatment alone. The courts perform only simple notarial functions. by certif ving to the gentineness of the papers, or to the professional standing of the physicians. In New Fork there is still noticeable in the procecdings a relic of the ancient law. The judge approves or not the eertificates, according to his discretion, though in this aet he is beliered to assume no other responsibility in the commitment than to certify to the proecedings. But, he may institute further investigations, and may even call a jury, and may submit the person to the ordinary trial of a petty criminal. In that respect the law adnits of great abuse. Practically, however, the commitment is on the decision of the cxamining physicians, the jutcre performing no other function than that of perfunctorily signing his name in approval."

In the law formulated by I)r. Smith, for the commitment of the insame in the Farious states, no new or untried scheme is proposed, but a law deduced from the varions laws now in use in the different states.

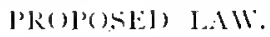

I. "No person shall be admitted to, or eonfined as a patient or inmate in, any hospital, asylum, or other institution, house or place, for the eare and treatment of the insane, exeept upon the certifieate of two physicians, as herein prorided."

To secure competent certifying physicians, the following section is suggested :

II. "It shall not be lawful for any physician to certify to the insanity of any person for the purpose of securing his commitment to eustody unless said plyysician be of reputable character, a graduate of some incorporated medical college, a resident of the state, and shall be in the actual practice of his profession, at the time of making said certificate." 
This, it will be notiecd. does away with the "three years in practice" repuirement of the present law. "This repurement, while intended to secure greater experience and competency in examiners does not always do so. "The error lies in the fact that the older practitionets have had little, if any, instruction in nerrous discases, and hence, are not really as eompetent as the recent graduates, who have attended courses of lectures on insanity, and have had the adrantage of elinical instronction. Sipeaking from personal experienee, in the exami. nation of thousands of certiflcates of insanity, we do not hesitate to state that those made by recent graduates are, as a rule, far more exact and complete than those made by old physicians."

III. "It shall not be law finl for a physician to certify to the insanity of any person for the purpose of commit. ting him to an asylum of which the said physician is either the superintendent physician, an offeer, or a regular professional attendant therein; nor shall it be lawful for a physician to certify to the insanity of any person to whom said physician is related by blood or matriage."

The last section of the proposed law contatins the method of securing judicial. sanction and force to the steps instituted.

"The eertificate herewith provided shall hare been made within one week of the cxamination of the patient, and within two weeks of the time of the admission of the patient, and shall be duly sworn to or affirmed before a judge of a court of record. who shatl certify to the genuineness of the signatures, and to the fact that the signers are duly qualified, as provided in section first of this act."

"This project of a law is submitted as embodying the principles which, in our opinion, should govern a state in the commitment of the insanc. 'The form may be modified to meet any existing conditions withont impairing these principles." 